\title{
Physics Teaching with Simulation Techniques
}

\author{
Mukul Kumar*, Babu Ram Tiwari \\ State Key Laboratory of Space Weather, National Space Science Center, Chinese Academy of Sciences, \\ Beijing, China-100190 \\ *Corresponding author email: mk.cas@yahoo.com \\ Received: 01 June 2018 / Revised: 25 June 2018 / Accepted: 29 June 2018 / Published: 30 June 2018

\begin{abstract}
The motivation of the present article is to focus on the enhancement of teaching and learning in Physics. This article emphasizes on the implementation of simulation and visualization techniques for physics teaching. A class is a union of different kind of students from different backgrounds and capabilities of learning. Some of them may visualize the problem in their mind while some of them may not. In that case, to better understand the problem, visualization of the problem may help the students to understand and to make an attempt at solving it.
\end{abstract}

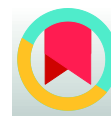

\section{Introduction}

To strengthen the teaching, learning and the education system, we need to implement some innovative teaching practices which will further lead to the social transformations (Nicolaides, 2012). The teaching and learning establish the relationship between the instructor, learners, experiments, environment of the classroom and the syllabus (SarÕçoban, 2010). The effectiveness of teaching is usually measured by the outcome of the class. In general, those who have a good command on their subject, have a good style of delivering their knowledge to their students, are masters in making a good communication with almost all the students in the class, who are able to reach every student are considered to the good instructors.

An Austrian philosopher and physicist Ernst Mach said: "Physics is experience, arranged in economic order". We live physics every day since we wake up till we sleep. We saw many incidents throughout the time happening around us e.g. the Sun rises in the morning and sets in the evening, the ice cube melts when we take it out of the freezer, the window glass breaks when a ball hits it, happening of the days and nights, happening of the solar eclipses and lunar eclipses and many other things we follow in our daily life are being dealt with the science of physics. We experience physics every day, we saw physics every day but we overlook its science because probably it is in our daily routine. Nature is the best physics teacher to teach the science of the physics only if we look at everything carefully.

The falling of an apple gave Newton's law; it's not like anyone else except Issac Newton did not see the apple falling on the ground. This is just the matter of perception, how we look the things happening around us. Physics deals with the study and transformation of matter and energy in different form. Being the fundamental science of life, Physics must be taught and learn in a very effective way. The effectiveness of physics teaching may vary with the style of teaching, techniques being used in teaching, the classroom management, the correlation between the instructor and the learners and so on. The present article is emphasizing the importance of simulation in physics teaching and recommends the implementation of the simulation techniques while teaching physics in the classroom.

\section{What is Simulation?}

Simulation is a particular type of modelling of real system which allows us to do experiment with it and to understand some very critical phenomenon. The simulations have been recognized as the way of understanding the world. We can simplify a structure and It can be used for different purposes e.g. for predictions as well for as a substitute for the experiments. Simulations are applicable in almost every field 
of science. Simulations are also considered as the verification methods for theoretical developments. For example, we cannot see what is happening on the Sun, but we are known to some of the physical quantities and conditions of the Sun. in that case, we can simulate this as a real system and can do experiments with it to understand the underlying science of physics. Shanon (1975) has defined the simulations as "the process of designing a model of a real system and conducting experiments with this model for the purpose either of understanding the behavior of the system or of evaluating various strategies (within the limits imposed by a criterion or set of criteria) for the operation of the system.” (Ingalls, 2008).

\section{Importance of Simulation in Physics Teaching}

The major goal of our physics education should be to help students in developing an understanding of physics concepts. Human beings are capable of understanding the world by making the mental models (Dervić et al. 2018, Greca \& Moreira (1997). Hence, these mental models can be considered equivalent to the reality and they allow the human beings to derive explanations and predictions of the physical system they represent (Dervić et al. 2018, Gentner \& Stevens, 1983; Johnson-Laird, 1983). However, these mental models can be made easier to make by integrating with external visualization (Rapp and Kurby, 2008). Using external visualizations we can improve the capabilities of learners by highlighting the important concepts of physics, by delivering the abstract information, giving hypothesis and solving problems (Dervić et al. 2018).

While making the visualizations, we should not forget to highlight the key features of the problem and to ensure that this visualization will help the learners to make predictions, to reach a conclusion (Dervić et al. 2018, Zou, 2000) and also to imagine beyond the problem described in the visualization. As the science of physics is directly and indirectly related to the routine human life, we should try our best to connect the visualization to the physics of daily life. One of the important cognitive activities needed to learn most of the physics concept is to establish the cause-and-effect relations. In general, developing mental models is easy for the learners if they can establish the cause-and-effect relationship. The simulation used to establishing the cause-and-effect relationships is said to be the interactive simulation in which a learner has the freedom to change the parameters and to visualize their effects (Dervić et al. 2018).

The cognitive load theory can help an instructor in designing and using the simulation during the instructions (Dervić et al. 2018). This theory said that the human working memory is comparatively less (Dervić et al. 2018). The work of Shell et al. 2009 reveals that the human working memory can only hold approximately 5-7 chunks of knowledge at the same time. In that case, an instructor has to be very careful towards the learners regarding this cognitive load (Dervić et al. 2018).

It has been seen that use of computer-based programs and simulations/ visualizations is increasing in the senior secondary level education of physics and chemistry (Park, et al., 2008; Phillips, Norris \& McNab, 2010). The use of simulations in classrooms is increasing as by doing this the students are being benefitted to understand that phenomenon which is even more difficult to understand using an instructor's lecture, with a drawing on a whiteboard or with a screen presentation (Fan \& Greelan 2012). There are a few books which collect the research on such new tools of teaching and learning (e.g. Gilbert 2005; Gilbert, Reiner and Nakhleh 2008). It is evident from the works of Annetta et al., 2009; Cifuentes and Hsieh, 2001 and Delgado \& Krajcik, 2010 that the scientific visualizations help the students to learn, understand and to increase their engagement with learning.

On the behalf of the discussions in the present article and the works carried out by several authors in education, Physics learning, education with simulations and cognitive sciences (e.g. Singh and Kumar, 2018, Dervić et al. 2018, Shell et al. 2009, Dervić et al. 2018, Zou, 2000, Greca \& Moreira 1997, Rapp and Kurby, 2008, Gentner \& Stevens, 1983; Johnson-Laird, 1983, Greelan 2012, Gilbert 2005, Gilbert, Reiner and Nakhleh 2008, Park, et al., 2008; Phillips, Norris \& McNab, 2010 and references cited therein) a general conclusion derived is that the simulation and visualizations are helpful to improve the learning capabilities of the targeted learners in the classroom. 


\section{Conclusion}

A classroom is a union of different learners from different backgrounds with different capacities of learning; an instructor should connect to every learner. As a group of learners may feel difficult to make mental models of the problem, the external visualizations may help them to make mental models and can motivate then further prediction and derive the conclusions. An instructor must be careful with the cognitive load. There are several meritorious students who in fact solve difficult numerical and theoretical problems of physics are not able to correlate the real-life incidents with the physical concepts. This is not because they can't do but this is probably because of the motivation in the right direction. Hence, in my opinion, an instructor must try to correlate the physics concepts with the daily life physics.

\section{Acknowledgements}

The Authors acknowledge Chinese Academy of Sciences, Beijing for financial support and State Key Laboratory of Space weather for providing fundamental facilities.

\section{How to Cite this Article}

Kumar, M. \& Tiwari, B. R. (2018, June 30). Physics Teaching with Simulation Techniques. Advanced Journal of Social Science, 4(1), 8-10. doi:10.21467/ajss.4.1.8-10

\section{References}

Annetta, L.A., Minogue, J., Holmes, S.Y. \& Cheng, M-T. (2009). Investigating the impact of video games on high school students' engagement and learning about genetics. Computers and Education, 53(1), 74-85.

Cifuentes, L. \& Hsieh, Y-C.J. (2001). Computer graphics for student engagement in science learning. TechTrends, 45(15), 21-23.

Delgado, C. \& Krajcik, J. (2010). Technology Supports for Science Learning. In P. Peterson, B. McGaw \& E. Baker (Eds.), International Encyclopedia of Education. Elsevier: Atlanta, GA.

Dervić, D., Glamočić, D.S., Azra, G.-B., Mešić, V. (2018). Teaching Physics with Simulations: teacher-centred versus student-centred approaches

Gentner, D., \& Stevens, A. (1983). Mental models. Hillsdale: Erlbaum

Greca, I. M., \& Moreira, M. A. (1997). The kinds of mental representations--models, propositions and images--used by college physics students regarding the concept of field. International Journal of Science Education, 19, 711-724

Gilbert, J.K. (2005). Visualization in Science Education. Springer: Dordrecht.

Gilbert, J.K, Reiner, M. \& Nakhleh, M. (2008). Visualization: Theory and practice in science education. Springer: Surrey.

Ingalls, R.G. (2008). Introduction to Simulation. In Proceedings of the 2008 Winter Simulation Conference, ed. S. J. Mason, R. R. Hill, L. Mönch, O. Rose, T. Jefferson, J. W. Fowler. Piscataway, New Jersey: Institute of Electrical and Electronics Engineers

Johnson-Laird, P. (1983). Mental models. Cambridge: Cambridge University Press.

Nicolaides A. (2012). Innovative teaching and learning methodologies for higher education Institutions, Educational Research (ISSN: 21415161) Vol. 3(8) pp. 620-626.

Park, J., Sandhu, M., Ritt, H., Pipes, D. \& Myers, J. (2008). Developing, testing, and implementing dynamic visualizations: integrating multiple representations of video, data, and graphs while investigating physical science concepts. In K. McFerrin et al. (Eds.), Proceedings of Society for Information Technology \& Teacher Education International Conference 2008 (pp. 4759-4765). Chesapeake, VA: AACE.

Phillips, L.M., Norris, S.P. \& McNab., J.S. (2010). Visualisations and science. Models and Modelling in Science Education, 5(2): 63-74.

Rapp, D. N., \& Kurby, C. A. (2008). The 'ins' and 'outs' of learning: Internal representations and external visualizations. In J. K. Gil-bert, M. Reiner, \& M. Nahkleh (Eds.), Visualization: Theory and practice in science education (pp. 29-52). Dordrecht: Springer

SarŌçoban A. (2010). Problems encountered by student-teachers during their practicum studies, Procedia Social and Behavioral Sciences 2 , pp. 707-711.

Shannon, R.E. (1975). Systems Simulation - The Art and Science, Prentice-Hall.

Shell, D.F., Brooks, D.W., Trainin, G., Wilson, K.M., Kauffman, D.F., \& Herr, L.M. (2009). The unified learning model. Dordrecht: Springer.

Singh, D., \& Kumar, M. (2018). Integration of Audio-Visual and Traditional Practices for Effective Classroom Teaching. Advanced Journal of Social Science, 3(1), 47-49.

Xinxin Fan, X., and Geelan, D., 2012, Fan Integrating Information Technology And Science Education For The Future: A Theoretical Review On The Educational Use Of Interactive Simulations, ACEC2012: ITs Time Conference, pp 1-9.

Zou, B.S.X. (2000). The use of multiple representations and visualizations in student learning of introductory physics: an example from work and energy. Ph.D. thesis, The Ohio State University.

Publish your research article in AIJR journals-

$\checkmark \quad$ Online Submission and Tracking

$\checkmark$ Peer-Reviewed

$\checkmark$ Rapid decision

$\checkmark \quad$ Immediate Publication after acceptance

$\checkmark \quad$ Articles freely available online

$\checkmark \quad$ Retain full copyright of your article.

Submit your article at journals.aijr.in
Publish your books with AIJR publisher-

$\checkmark \quad$ Publish with ISBN and DOI.

Publish Thesis/Dissertation as Monograph.

Publish Book Monograph.

Publish Edited Volume/ Book.

Publish Conference Proceedings

Retain full copyright of your books.

Submit your manuscript at books.aijr.org 